\title{
Spectrophotometric determination of cefixime by charge transfer complex formation
}

\author{
Farha Khalaf Omar* \\ Received 18, June, 2012 \\ Accepted 4, December, 2012
}

\begin{abstract}
:
Simple, sensitive and economical spectrophotometric methods have been developed for the determination of cefixime in pure form. This method is based on the reaction of cefixime as n-electron donor with chloranil to give highly colored complex in ethanol which is absorb maximally at $550 \mathrm{~nm}$. Beer's law is obeyed in the concentration ranges 5-250 $\mu \mathrm{g} \mathrm{ml}^{-1}$ with high apparent molar absorptivities of $1.52 \times 10^{3}$ L.mole ${ }^{-1} . \mathrm{cm}^{-1}$.
\end{abstract}

Key words: cefixime; chloranil ;charge-transfer complexes; aqueous solution.

\section{Introduction:}

The charge transfer complexes are formed between electron donors, having sufficiently low ionization potential, and acceptors, having sufficiently high electron affinity. The transfer of an electron from a donor to an acceptor is readily possible in the charge transfer process[1] .

Cefixime tri hydrate is 5-Thia-1azabicyclo[4.2.0] oct-2-ene-2carboxylic acid, 7-[[(2- amino-4thiazolyl) [(caroxymethoxy)imino] acetyl] amino]-3-ethenyl-8-oxotrihydrate fig (1)[2] Cefixime is effective against a wide spectrum of sensitive Gram -Ve, Gram +Ve and anaerobic bacterial pathogens including $\beta$ - lactamase producing strains[3]. Cefixime is given by mouth in the treatment of susceptible infections including gonorrhoea, otitis media, pharyngitis, lower respiratorytract infections such as bronchitis, and urinary-tract infections[4].<smiles>C=CC1=C(C(=O)O)N2C(=O)[C@H](NC(=O)/C(=N\OCC(=O)O)c3csc(N)n3)[C@@H]2SC1</smiles>

Chemical Structure of Cefixime M.wt. $=507.5$

Literature survey reveals that various high-performanceliquid chromatographic (HPLC) methods have been reported for the determination of cefixime. $[2,5-8]$ and by HPTLC[9] individually or with other drugs, spectrophotometric methods[10-11]

In this paper we report a simple, sensitive, and accurate, spectrophotometric method for the determination of cefixime in pure form and in pharmaceutical formulations

\section{Materials and Methods:} Apparatus

All spectral measurements were performed on Shimadzu U.V-visible recording spectrophotometer (U.V160), where as absorbance

*Chemistry Department, Education College for Girls, Mosul University 
measurements were carried out on CECIL-CE-1021spectrophotometer. $\mathrm{pH}$ measurements are carried out using a Philips PW 9420 pH meter.

\section{Reagents}

Chemicals used are of the highest purity available.

Chloranil solution: A saturated $\left(1 \times 10^{-}\right.$ $\left.{ }^{3} \mathrm{M}\right)$ ethanol solution was used. Borate Buffer solution: borate buffer solution of $\mathrm{pH} 9$ is obtained by preparation of $\left(5 \times 10^{-2} \mathrm{M}\right)$ sodiumtetraborate in aqueous solution.

Standard solutions of cefixime: $(1000 \mu \mathrm{g} / \mathrm{ml}): 0.1 \mathrm{~g}$ is dissolved in ethanol, solution is transferred into a $100 \mathrm{ml}$ volumetric flask, and diluted to the mark with absolut ethanol

Ethanol: Absolute( $100 \%)$ is used.

\section{Recommended procedure}

Aliquots of standard cefixime solutions were transferred separately into a series of $25 \mathrm{ml}$ calibrated flasks. To each of these were added $2.0 \mathrm{ml}$ of $1 \times 10^{-3} \mathrm{M}$ chloranil followed by addition $2 \mathrm{ml}$ of borate buffer solution and the solutions were heated at $30^{\circ} \mathrm{C}$ for $5 \mathrm{~min}$., then the solutions were cooled to room temperature and diluted to the mark with ethanol. The absorbances of the products was measured at $550 \mathrm{~nm}$ against corresponding reagent blank.

\section{Results and Discussion:}

\section{Absorption spectra}

cefixime reacted with chloranil reagent in the presence of a base and produced a yellow color with chloranil having maximum absorption at $550 \mathrm{~nm}$ against respective reagent blank (Fig.

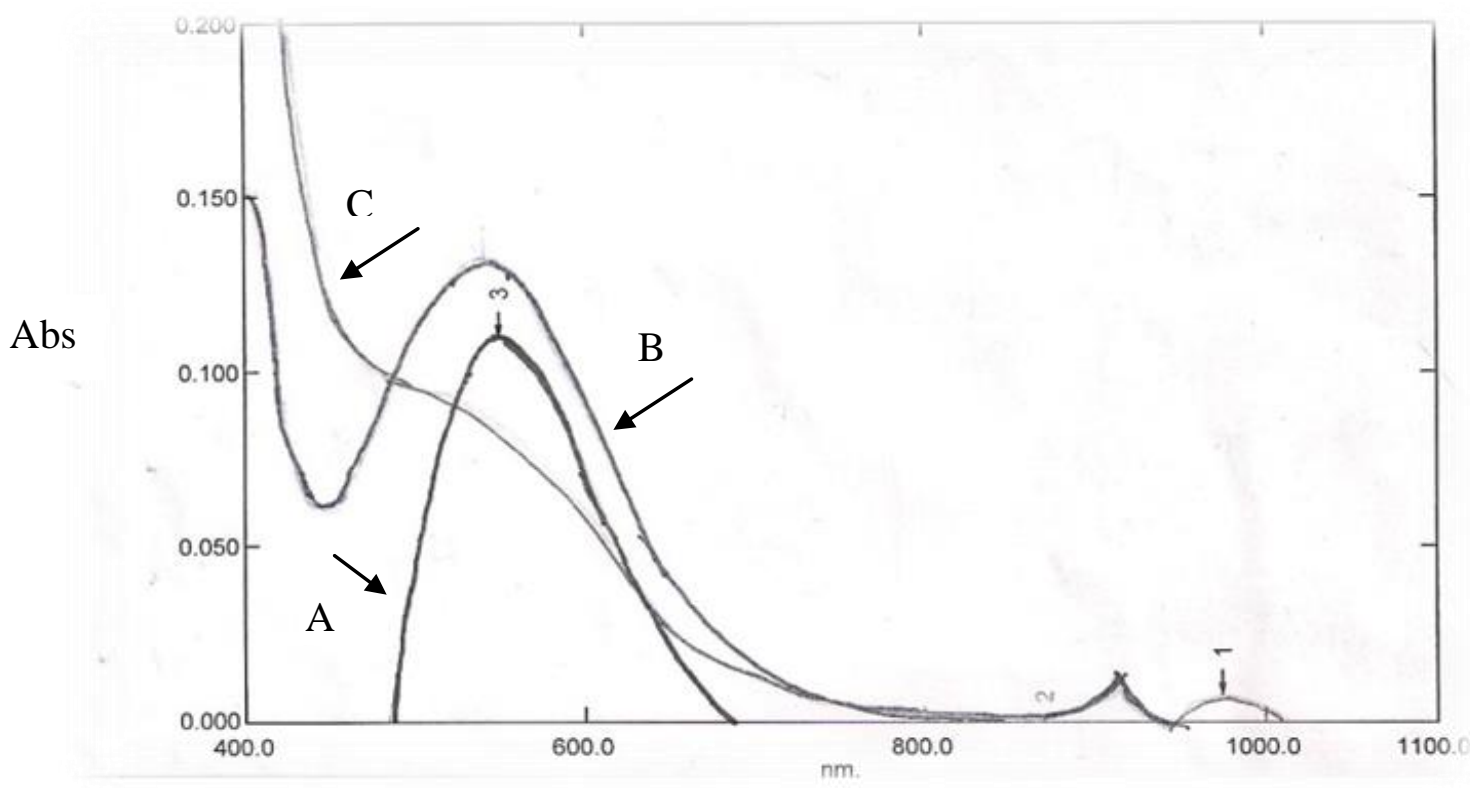

1).

Wavelength(nm)

$A=(S \& b), B=(S \& w), C=(b \& w)$

Fig(1.) Absorption spectra of cefixime $(30 \mu \mathrm{g} / 25 \mathrm{ml})$ complex with chloranil reagent $\left(1 \times 10^{-3} \mathrm{M}\right)$ 


\section{Study of the optimum reaction conditions}

The effect of various parameters on the absorption of the coloured CT complex formed with chloranil have been investigated and the reactions conditions have been optimized for cefixime.

\section{Effect of pH and buffer solutions on the absorbance}

The effect of $\mathrm{pH}$ on the absorption of cefixime - chloranil product was studied using different concentrations of $\mathrm{HCl}$ and $\mathrm{NaOH}$ of $\mathrm{pH}$ ranging from 5-10. It was found that the product cefixime -chloranil formed in the final pH9 in the presence of sodium hydroxide. Different buffers of $\mathrm{pH} 9$ namely bicarbonate, borate, phosphate buffers were prepared to examine the sensitivity of cefixime -chloranil product. (Table 1) shows that maximum absorption is obtained by using a borate buffer solution. However, the optimum amount of this buffer has been investigated and it was found that $2 \mathrm{ml}$ of aliquots gave maximum absorbance and selected in subsequent experiments.

Table (1): Effect of different buffers of $\mathbf{p H}$

\begin{tabular}{|l|l|l|l|}
\hline Buffer & Bicarbonate & Borate & Phosphate \\
\hline Absorbance & 0.261 & 0.355 & 0.245 \\
\hline
\end{tabular}

2. Effect of reaction time and temperature

The reaction time was determined by following the colour development at room temperature and in thermostatically controlled water-bath at different temperatures. The absorbance was measured against reagent blank treated similarly at 550 nm. It was observed that the absorbance reached maximum after addition of the reagent solutions after 5 min at $\left(35^{\circ} \mathrm{C}\right)$ (Table 2). These temperature and reaction time was chosen for colour development.

Table (2): Effect of reaction time\& temperature on absorbance

\begin{tabular}{|c|c|c|c|c|c|c|c|c|c|}
\hline \multirow{2}{*}{ Temp $^{\circ} \mathrm{C}$} & \multicolumn{9}{|c|}{ Absorbance } \\
\cline { 2 - 11 } & \multicolumn{9}{|c|}{ Time (min) } \\
\hline & immediately & 5 & 10 & 15 & 20 & 25 & 30 & 35 & 40 \\
\hline 0 & 0.213 & 0.211 & 0.210 & 0.210 & 0.210 & 0.210 & 0.210 & 0.210 & 0.210 \\
\hline 25 & 0.350 & 0.350 & 0.351 & 0.351 & 0.351 & 0.351 & 0.351 & 0.351 & 0.351 \\
\hline 30 & 0.350 & 0.358 & 0.358 & 0.358 & 0.358 & 0.358 & 0.358 & 0.358 & 0.358 \\
\hline 35 & 0.361 & 0.363 & 0.363 & 0.363 & 0.363 & 0.363 & 0.363 & 0.363 & 0.363 \\
\hline 40 & 0.361 & 0.362 & 0.363 & 0.363 & 0.364 & 0.363 & 0.632 & 0.363 & 0.363 \\
\hline 45 & 0.360 & 0.361 & 0.363 & 0.364 & 0.363 & 0.363 & 0.363 & 0.362 & 0.363 \\
\hline
\end{tabular}

\section{Effect of reagent concentration}

The effect of changing the reagent concentration on the absorbance of solution containing a fixed amount of cefixime was studied, It was found, as shown in (Table 3), that absorbance increases with increasing choranil concentration and reached their maximum value on using $2 \mathrm{ml}$ of $1 \times 10^{-3} \mathrm{M}$ of chloranil which was used in subsequent experiments.
Table (3) Effect of the reagent concentration on absorbance

\begin{tabular}{|l|l|l|l|l|l|}
\hline $\begin{array}{l}\text { Chloranil(1× } \\
\left.\mathbf{1 0}^{-3} \mathbf{M}\right) \mathbf{m l}\end{array}$ & 1 & 1.5 & 2 & 2.5 & 3 \\
\hline Absorbance & $\begin{array}{l}0.35 \\
7\end{array}$ & $\begin{array}{l}0.36 \\
0\end{array}$ & $\begin{array}{l}0.36 \\
5\end{array}$ & $\begin{array}{l}0.36 \\
2\end{array}$ & $\begin{array}{l}0.35 \\
9\end{array}$ \\
\hline
\end{tabular}

\section{Effect of surfactant}

Effect of various anionic, cationic and neutral surfactants including sodium dodecyl sulphate (SDS), , cetavlon (CTAB), and triton $\mathrm{X}-100$ were tested for the investigation of the sensitivity of the method. The results reveal that the presence of the 
surfactants has no remarkable effect on the intensity of the colour. Therefore, the methods have been carried out without using surfactants.

\section{Effect of order of addition}

In order to obtain the high colour intensity, the order of addition of reagents should be followed as given in the recommended procedures, otherwise a loss in colour intensity was observed.

\section{Quantification and Analytical Data}

The results for the determination of cefixime is summarized in Table 4, which show the sensitivity, recovery and reproducibility of the proposed method. These are reasonably precise and accurate. The calibration graph is linear in the range of 5-250 $\mu \mathrm{gml}^{-1}$. The apparent molar absorptivities calculated is $1.52 \times 10^{3} \mathrm{~mol}^{-1} \mathrm{~cm}^{-1}$, Table 4 illustrates regression equations, and correlation coefficients $\left(\mathrm{R}^{2}\right)$ for the proposed methods. The reproducibility of the proposed method was checked by estimating three different concentration levels within the Beer's law limit in five replicates. The average recovery were $96.54 \%$ reveal good accuracy for the method. The relative standard deviation can be considered to be very satisfactory.

Table (4). Quantitative parameters of the proposed method.

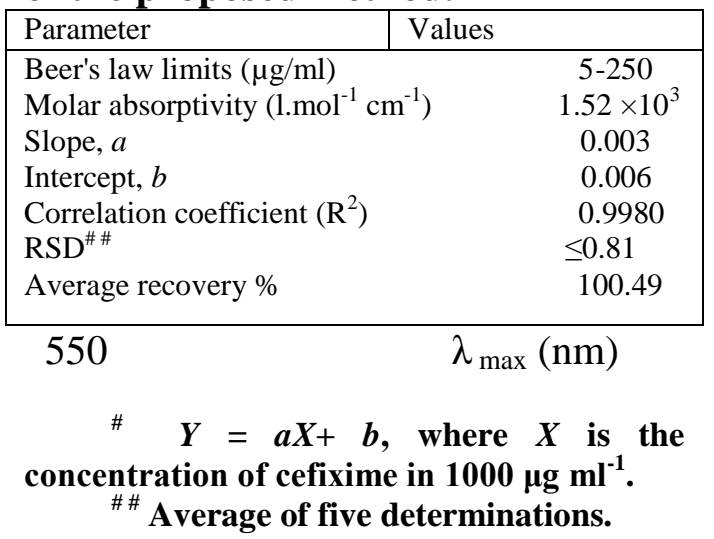

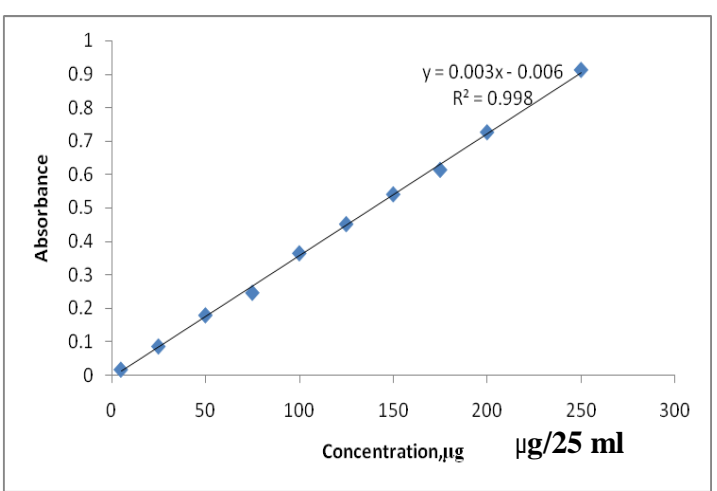

Fig. (2) Calibration graph for cefixime.

\section{Accuracy and precision}

The accuracy and precision of the method were evaluated by performing five replicate analyses of cefixime in pure form at four different concentration levels $(5,50,100,200 \mu$ g.ml-1). The mean recovery $(99.90 \%)$ and relative standard deviation $(<0.81)$ can be considered to be very satisfactory.

\section{Analytical application}

The contents of 5 tablets $(200 \mathrm{mg}$ ) were weighed and the powder was mixed. The accurately weighed portion of the powder equivalent to $100 \mathrm{mg}$ dissolved in amount of ethanol. The solution was filtered into a $100 \mathrm{ml}$ calibrated flask, the residue was washed with ethanol and the filtrate was diluted to the mark with ethanol. Different volumes of this solution were transferred to cover the concentrations $25,50,100 \mu \mathrm{g} / \mathrm{ml}$ of cefixime and proceeded as a procedure described above. The data are given in Table5.

Table (5.) Determinations of cefixime in tablets

\begin{tabular}{|l|l|l|l|}
\hline $\begin{array}{l}\text { Amount } \\
\text { added } \\
(\mu \mathrm{g} / \mathrm{ml})\end{array}$ & Found $(\mu \mathrm{g} / \mathrm{ml})$ & $\begin{array}{l}\text { Average } \\
\text { recovery } \\
(\%)\end{array}$ & Recovery* $(\%)$ \\
\hline 25 & 24.86 & \multirow{2}{*}{100} & 98.80 \\
\hline 50 & 50.89 & & 100.89 \\
\hline 100 & 101.9 & 101.42 \\
\hline
\end{tabular}


Stioicheiometry of the reaction :

The mole ratio method (12) was employed to establish the composition of the complex ,the result indicate the formation of a 1:1 complex between cefixime and chloranil at $550 \mathrm{~nm}$. Thus the suggested reaction might be written as;<smiles>C=CC1=C(C(=O)O)N2C(=O)[C@H](NC(=O)/C(=N/OCC(=O)O)c3csc(N)n3)[C@H]2SC1</smiles>

Donor

Acceptor

\section{Conclusion:}

It is thus concluded that the proposed method is simple, cost effective, accurate, safe, free from pollution and precise and can be successfully employed in the routine analysis of this drug in pharmaceutical tablet dosage forms.

\section{Reference:}

1-Hassib, H. and Issa ,Y. 1996.Conductimetric studies of charge transfer complexes of some benzylidine aniline Schiffs bases with substituted p-benzoquinones ;Egypt.J.Anal.Chem, 39(4):329338.

2-British pharmacopoeia , 2009. Stationery office ,London ,UK,.PP.1139.

3-Wilson and Gisvold's,1998.; Text book of organic andmedicinal and pharmaceutical chemistry;, Jaime N.Delgado and William A. Remers Lippincott - $\quad$ Raven Philadelphia.10th Edition, pp-287.

4-Martindale. 1996.The Extra Pharmacopeia, 31st ed., Roya Pharmaceutical Society, London : $186-190$
5- The United State Pharmacopeia Convection. 2009. Inc, 32-NF, 27:1834-1835.

6-Rathinavel, G. etal. 2008.A validated RP-HPLC method of simultaneous estimation of Cefixime and Cloxacillin in tablets"E- J.chem., 5( 3) : 648-651.

7-Zendelovska,D. etal. 2003. HPLC method for determination of cefixime and cefotaxim in human plasma Bulletin of the Chemists and technologists of Macedonia, 22(1):39-45.

8-Kumudhavalli ,M.V ., Sahu , S,Abhiteja, K., Jayakar and Dr. B. 2010. Development And Validation Of Rp-Hplc Method For Simultaneous Determination of Cefixime And Potassium Clavulanate In Tablet Dosage Form; Inter. J. Pharma. Rec. Res.2(2): 57-60.

9- Jovanovic,S. Agbaba,D. Stakic,D. and Vladimirov,S. 1998.HPTLC determination of ceftriaxone, cefixime and cefotaxime in dosage form ; J.Pharm.Biomed. Anal,18 (1):893-898.

10- Nanda ,R. Gaikwad ,J. and Prakash, A. 2009. Simultaneous spectrophotometric estimation of 
cefixime and ornidazole in tablet dosage form ;Intern.J. Pharm .Tech. Res.,1(3):488- 491.

11- Maheshwari,R. Kinariwala ,M . Saxena, M. and Jagwani, Y. 2008. Spectrophotometric Analysis of Cefixime trihydrate tablets using metformin hydrochloride as hydrotropic soluilizing agent; Asian J. Chem,20:6047-6050.

12-.Bauer H.H,.Christian G.D and Oreilly J.E; Instrumental Analysis ; Allyn and Bacon, Inc . Boston, 1978. PP:178- 179.

\section{التقدير الطيفي للسيفيكسيم بواسطة معقدات انتقال الشحنة}

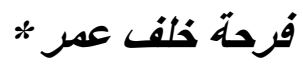$$
\text { *جامعة الموصل - كلية النربية للبنات ـ قسم الكيمياء }
$$

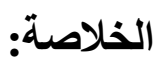

تم تطوير طريقة طيفية تميزت بالبساطة و الحساسية في تقدير سيفكسيح. اعنمدت الطريقة على تفاعل

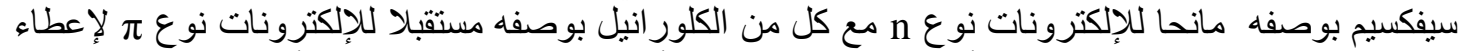

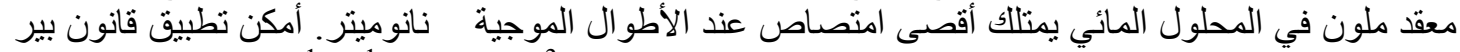

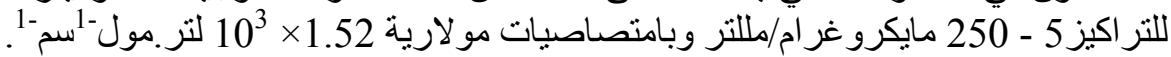

